\title{
Particle water and pH in the eastern Mediterranean: source variability and implications for nutrient availability
}

\author{
Aikaterini Bougiatioti ${ }^{1,2}$, Panayiota Nikolaou ${ }^{1}$, Iasonas Stavroulas $^{1}$, Giorgos Kouvarakis $^{1}$, Rodney Weber $^{2}$, \\ Athanasios Nenes $^{2,3,4}$, Maria Kanakidou ${ }^{1}$, and Nikolaos Mihalopoulos ${ }^{1,4}$ \\ ${ }^{1}$ Environmental Chemical Processes Laboratory, University of Crete, 71003 Crete, Greece \\ ${ }^{2}$ School of Earth and Atmospheric Sciences, Georgia Institute of Technology, Atlanta, GA 30332, USA \\ ${ }^{3}$ School of Chemical and Biomolecular Engineering, Georgia Institute of Technology, Atlanta, GA 30332, USA \\ ${ }^{4}$ IERSD, National Observatory of Athens, 15236 Athens, Greece
}

Correspondence to: Nikolaos Mihalopoulos (mihalo@uoc.gr) and Aikaterini Bougiatioti (kbougiatioti@gmail.com)

Received: 21 October 2015 - Published in Atmos. Chem. Phys. Discuss.: 29 October 2015

Revised: 9 March 2016 - Accepted: 24 March 2016 - Published: 13 April 2016

\begin{abstract}
Particle water (liquid water content, LWC) and aerosol $\mathrm{pH}$ are important parameters of the aerosol phase, affecting heterogeneous chemistry and bioavailability of nutrients that profoundly impact cloud formation, atmospheric composition, and atmospheric fluxes of nutrients to ecosystems. Few measurements of in situ LWC and $\mathrm{pH}$, however, exist in the published literature. Using concurrent measurements of aerosol chemical composition, cloud condensation nuclei activity, and tandem light scattering coefficients, the particle water mass concentrations associated with the aerosol inorganic $\left(W_{\text {inorg }}\right)$ and organic $\left(W_{\text {org }}\right)$ components are determined for measurements conducted at the Finokalia atmospheric observation station in the eastern Mediterranean between June and November 2012. These data are interpreted using the ISORROPIA-II thermodynamic model to predict the $\mathrm{pH}$ of aerosols originating from the various sources that influence air quality in the region. On average, closure between predicted aerosol water and that determined by comparison of ambient with dry light scattering coefficients was achieved to within $8 \%$ (slope $=0.92, R^{2}=0.8, n=5201$ points). Based on the scattering measurements, a parameterization is also derived, capable of reproducing the hygroscopic growth factor $(f(\mathrm{RH}))$ within $15 \%$ of the measured values. The highest aerosol water concentrations are observed during nighttime, when relative humidity is highest and the collapse of the boundary layer increases the aerosol concentration. A significant diurnal variability is found for $W_{\text {org }}$ with morning and afternoon average mass concentrations being $10-15$ times lower than nighttime concentra-
\end{abstract}

tions, thus rendering $W_{\text {inorg }}$ the main form of particle water during daytime. The average value of total aerosol water was $2.19 \pm 1.75 \mu \mathrm{g} \mathrm{m}^{-3}$, contributing on average up to $33 \%$ of the total submicron mass concentration. Average aerosol water associated with organics, $W_{\text {org }}$, was equal to $0.56 \pm 0.37 \mu \mathrm{g} \mathrm{m}^{-3}$; thus, organics contributed about $27.5 \%$ to the total aerosol water, mostly during early morning, late evening, and nighttime hours.

The aerosol was found to be highly acidic with calculated aerosol $\mathrm{pH}$ varying from 0.5 to 2.8 throughout the study period. Biomass burning aerosol presented the highest values of $\mathrm{pH}$ in the submicron fraction and the lowest values in total water mass concentration. The low $\mathrm{pH}$ values observed in the submicron mode and independently of air mass origin could increase nutrient availability and especially P solubility, which is the nutrient limiting sea water productivity of the eastern Mediterranean.

\section{Introduction}

Atmospheric particles have the ability to absorb significant amounts of water, which profoundly affects their physical and chemical properties (Khlystov et al., 2005) and impacts on atmospheric processes and health. Ambient concentrations of aerosol liquid water are controlled by the aerosol chemical composition, relative humidity (RH), and temperature, as they are largely in chemical equilibrium with the surrounding water vapor. Liquid water is ubiquitous and ex- 
ceeds the total aerosol dry mass by 2 to 3 times on a global scale (Liao and Seinfeld, 2005). Therefore, the aerosol liquid water content (LWC) increases the particle size, affecting the particle lifetime and scattering efficiency. LWC and its strong dependence on RH are the most important contributors to aerosol direct radiative cooling by aerosols (Pilinis et al., 1995). Numerous modeling studies suggest that reactions in aerosol liquid water are an important pathway of secondary organic aerosol (SOA) formation (Carlton and Turpin, 2013; Myriokefalitakis et al., 2011), thus playing an important role in the overall aerosol chemical composition. Aerosol water also has a profound impact on the aerosol phase state, being able to transform semisolid and viscous particles into homogeneous phase that are in equilibrium with their environment (Pöschl and Shiraiwa, 2015). This affects the timescale of heterogeneous reactions and ice nucleation. Nevertheless, despite the abundance and importance of LWC, it is not routinely measured, actual mass concentrations are uncertain, especially in the presence of organic compounds, and model predictions of the property are often not evaluated (Nguyen et al., 2014).

Apart from the LWC, the $\mathrm{pH}$ of aqueous aerosols is another critically important aerosol property that drives many processes related to the aerosol chemical composition and gas-aerosol partitioning (Guo et al., 2015; Surratt et al., 2007, 2010; Meskhidze et al., 2003; Eddingsaas et al., 2010; Myriokefalitakis et al., 2015). Direct measurements of aerosol pH "in situ" are scarce (e.g., Keene et al., 2002, 2004) and require careful consideration owing to the nonconserved nature of the hydronium ion and partial dissociation of inorganic and organic electrolytes in the aerosol. These challenges have led to the suggestion that indirect alternatives - such as measuring the semi-volatile partitioning of key species sensitive to $\mathrm{pH}$ - combined with comprehensive models may provide a reasonably accurate estimate of $\mathrm{pH}$ that can be carried out with routine measurements (Hennigan et al., 2015). The most frequently used proxy is the "ion balance", where the charge balance of measurable anions and cations is calculated, with the exception of the hydronium and hydroxyl ions; a surplus of cations implies an alkaline aerosol and vice versa. Often it is implied that a larger value of the ion balance implies a stronger acidity/alkalinity. As shown by Hennigan et al. (2015) and Guo et al. (2015), the ion balance (and other similar proxies discussed in Hennigan et al., 2015) fail in general to represent the true aerosol $\mathrm{pH}$; only meticulous measurement of semi-volatile species (such as ammonia or ammonium) and other aerosol chemical constituents, combined with appropriate thermodynamic calculations (e.g., with ISORROPIA-II; Fountoukis and Nenes, 2007) are able to realistically provide particle pH and LWC (Hennigan et al., 2015). For an accurate and unbiased $\mathrm{pH}$ calculation both gas and aerosol phase concentrations are needed; however, when some uncertainty can be tolerated or the level of $\mathrm{pH}$ bias is known, aerosol measurements alone can still be quite informative for determining the $\mathrm{pH}$, as demonstrated by Guo et al. (2015).

Directly linked to aerosol $\mathrm{pH}$ and LWC is the bioavailability of nutrients contained within dust, involving $\mathrm{pH}-$ dependent catalyzed redox-reaction pathways; upon deposition, increased availability of these nutrients may promote primary productivity in continental and marine ecosystems (e.g., Meskhidze et al., 2003; Nenes et al., 2011; Mahowald et al., 2008, 2009; Krishnamurthy et al., 2010). Acids (such as sulfuric and nitric) generated in the atmosphere from a variety of anthropogenic and biogenic sources, when mixed with mineral aerosols in sufficient amounts, could lower the aerosol $\mathrm{pH}$ to values that increase the solubilities of Fe- and P-containing minerals by several orders of magnitude (Stumm and Morgan, 1996; Shi et al., 2012). Nenes et al. (2011) have demonstrated that acidification can release considerable amounts of soluble phosphorus from minerals originating from soil (e.g., 81-96\% of the total P found in Saharan dust and soil). Apart from P, the transport and deposition of mineral dust is believed to be a major, if not the dominant source of Fe to the remote ocean (Jickells et al., 2005). Considering the mixing of $\mathrm{SO}_{2}$ with advected dust plumes and the subsequent acidification of dust through heterogeneous and gas phase processes, Meskhidze et al. (2003) concluded that for aerosol with $\mathrm{pH}<2,1-2 \%$ of the contained Fe would be mobilized within 3-5 days. Meskhidze et al. (2005) also demonstrated that sufficient acidification of Asian dust plumes could drive, upon deposition, a phytoplankton bloom in high-nitrate low-chlorophyll regions of the North Atlantic. Solmon et al. (2009) also showed that simulated enhancements in particulate soluble iron driven by the chemical dissolution mechanism can range from 0.5 to $6 \%$, which is consistent with observations over the North Pacific Ocean.

The eastern Mediterranean, being at the nexus of three continents (Europe, Asia and Africa), receives air masses influenced by a spectrum of human (traffic, biomass burning, and industry) and natural (dust and marine) sources. It is therefore an ideal location to study atmospheric acidification of aerosols; however, to date, very few studies have accomplished that.

This study uses aerosol chemical composition measurements in conjunction with cloud condensation nuclei (CCN) concentration and light scattering coefficient $\left(\sigma_{\mathrm{sp}}\right)$ measurements to model the water mass concentrations (LWC) of aerosols from various sources in the eastern Mediterranean. These data are then used in combination with the ISORROPIA-II thermodynamic equilibrium model (Fountoukis and Nenes, 2007) to predict the aerosol $\mathrm{pH}$ for air masses that influenced air quality in the eastern Mediterranean during the late summer and fall months of 2012. 


\section{Instrumentation and methods}

\subsection{Measurement site}

Aerosol measurements were conducted at the Finokalia atmospheric observation station in Crete, Greece $\left(35^{\circ} 20^{\prime} \mathrm{N}\right.$, $25^{\circ} 40^{\prime}$ E; $250 \mathrm{~m}$ a.s.1.), between August and November 2012. The site (http://finokalia.chemistry.uoc.gr/) is a European supersite for atmospheric aerosol research and is part of the ACTRIS Network (Aerosols, Clouds, and Trace gases Research Infrastructure) (http://www.actris.eu/). The station is located in the northeastern part of the island of Crete, facing the Mediterranean Sea and covering the whole northern sector. Being away from direct urban influence, the station is representative of background measurements in the eastern Mediterranean, and sampled air masses arriving at the site most commonly have a marine source region or originate from continental Europe and the Greek mainland. Moreover, dust events from northern Africa (Sahara) occur often during spring and autumn. More details of the Finokalia station and the prevailing climatology in the area are given by Mihalopoulos et al. (1997).

\subsection{Instrumentation}

$\mathrm{PM}_{1}$ (particulate matter with a diameter smaller than $1 \mu \mathrm{m}$ ) aerosol light scattering coefficients $\left(\sigma_{\mathrm{sp}}\right)$ were measured online with the use of two different nephelometers to infer the LWC. Particle dry scattering was measured with a threewavelength Aurora 1000 Integrating Nephelometer, located in an air-conditioned sampling trailer and operated with a diffusional silica dryer upstream, which maintained the RH below $35 \%$. Based on the ISORROPIA model run for metastable ammonium sulfate aerosol at an RH of $30 \%$, the maximum water which can be contained under these conditions is $1.21 \mu \mathrm{g} \mathrm{m}^{-3}$, which is less than $12 \%$ of the total submicron aerosol mass. The nephelometer for the particle wet scattering was a Radiance Research M903, located outside the trailer in order to provide a scattering measurement at ambient temperature $(T)$ and RH. This second nephelometer was equipped with a VAISALA Inc. Humitter 50U Integrated Humidity and Temperature probe in order to record the ambient values of $T$ and RH with an accuracy specified to be better than $\pm 5 \% \mathrm{RH}$ at $20^{\circ} \mathrm{C}$. Both nephelometers take part in yearly intercomparisons within the ACTRIS network.

The real-time, quantitative measurements of the nonrefractory components of the submicron aerosol were provided by an Aerodyne Research Inc. Aerosol Chemical Speciation Monitor (ACSM; Ng et al., 2011). Ambient air was draw into the ACSM by a multiple $\mathrm{PM}_{10}$ (particulate matter with a diameter smaller than $10 \mu \mathrm{m}$ ) aerosol inlet operating at Finokalia, with a temporal resolution of $30 \mathrm{~min}$. At the inlet of the ACSM and via a critical aperture mounted at the entrance of an aerodynamic lens, the submicron fraction of the aerosol is sampled. The aerodynamic lens of the ACSM allows for the detection of particles of up to $700 \mathrm{~nm}$ diameter. The focused particle beam is then transmitted through two vacuum chambers and into a detection chamber where the particles impact on a hot plate and are flashvaporized. Finally, they are detected and characterized with the use of an electron impact quadrupole mass spectrometer. Constituents quantified by the ACSM include organics, sulfate, ammonium, nitrate, and chloride. Detection limits for all constituents for $30 \mathrm{~min}$ of averaging time are provided by $\mathrm{Ng}$ et al. (2011) and are $0.284,0.148,0.024,0.012$, and $0.011 \mathrm{\mu g} \mathrm{m}^{-3}$ for ammonium, organics, sulfate, nitrate, and chloride, respectively. Mass concentrations are calculated with the recommended collection efficiency of 0.5 for all constituents ( $\mathrm{Ng}$ et al., 2011), and the main aerosol constituents, i.e., organics, sulfate, and ammonium, are verified by comparison with other concurrent measurements (daily $\mathrm{PM}_{1}$ filters; Bougiatioti et al., 2014, Supplement). $\mathrm{PM}_{1}$ filters (Pallflex Tissuquartz, $47 \mathrm{~mm}$ diameter) were collected using a built-in system comprised of the four upper stages (stage 8-11) of a low-pressure Berner impactor (PLBI; Berner and Lürzer, 1980). Furthermore, daily $\mathrm{PM}_{10}$ filters are also collected on site using a sequential sampler (Leckel, SEQ47/50). A detailed study of the comparison between ACSM and $\mathrm{PM}_{1}$ filter values for a large subset of the present data (16 August30 September 2012) is provided by Bougiatioti et al. (2014).

$\mathrm{PM}_{1}$ and $\mathrm{PM}_{10}$ filters were analyzed by ion chromatography (IC) for anions $\left(\mathrm{Cl}^{-}, \mathrm{Br}^{-}, \mathrm{NO}_{3}^{-}\right.$(nitrate), $\mathrm{SO}_{4}^{-2}$ (sulfate), $\mathrm{C}_{2} \mathrm{O}_{4}^{-2}$ (oxalate)) and cations $\left(\mathrm{K}^{+}, \mathrm{Na}^{+}, \mathrm{NH}_{4}^{+}, \mathrm{Mg}^{2+}, \mathrm{Ca}^{2+}\right.$ ) using the procedure described by Bardouki et al. (2003). From the calcium, the crustal component can be estimated by subtracting the contribution of sea salt $\mathrm{Ca}^{2+}=[\mathrm{Na}] \cdot 0.038$, and dust concentration is estimated using the approach of Sciare et al. (2005). Based on the study by Koulouri et al. (2008) for a 2-year period at the same sampling site, it has been demonstrated that for fine particles (in that case $\left.D_{\mathrm{a}}<1.3 \mu \mathrm{m}\right)$ the contribution of the marine source to the aerosol mass was $10 \%$. Similarly, dust contribution in the fine fraction can vary between 6 and $10 \%$ for summer and winter, respectively.

From 25 June to 7 August 2014, gas phase ammonia measurements were also conducted at Finokalia, using a wet annular denuder (WAD; Wyers et al., 1993; Spindler et al., 2003) coupled with an ion chromatography system quantifying cations with an hourly resolution in order to check the validity of our calculations in the absence of gaseous phase $\mathrm{NH}_{3}$ (see Sect. 2.4). Concurrent black carbon (BC) measurements were performed on site using a seven-wavelength aethalometer (Magee Scientific, AE31) with a time resolution of $5 \mathrm{~min}$. Based on previous studies at Finokalia, BC is found mainly on the fine aerosol fraction (Koulouri et al., 2008; Bougiatioti et al., 2014); hence, these values are used in addition to the ACSM concentrations to calculate the dry aerosol mass of the $\mathrm{PM}_{1}$ fraction. 
Size-selected cloud condensation nuclei $(\mathrm{CCN})$ measurements were obtained using a Droplet Measurement Technologies, Continuous Flow Streamwise Thermal Gradient CCN counter (CFSTGC; Roberts and Nenes, 2005). Particles of $60,80,100$, and $120 \mathrm{~nm}$ were first size-selected by a differential mobility analyzer (DMA), split into two, and one of these flows was introduced into the $\mathrm{CCN}$ counter. The total number of condensation nuclei $(\mathrm{CN})$ was measured by a condensation particle counter (CPC; TSI 1772) situated downstream of the first DMA. In the CCN counter, the activated droplets are sized and counted by an optical particle counter (OPC) after exiting the growth chamber. The instrument was operated in scanning flow $\mathrm{CCN}$ analysis mode (SFCA; Moore and Nenes, 2009), where the flow rate in the growth chamber changes over time, while a constant temperature difference is maintained. In that way the supersaturation changes continuously, providing activation spectra with a high temporal resolution. The flow rate was increased linearly between a minimum and a maximum flow rate and sigmoidal activation curves of $\mathrm{CCN}$ vs. flow rate were recorded, with the inflection point of the sigmoid representing a critical activation flow, $Q_{50}$, that corresponds to a critical supersaturation, $S^{*}$, above which particles act as $\mathrm{CCN}$. From the critical supersaturation and knowledge of the particle dry diameter, with the application of Köhler theory, the hygroscopicity parameter $\kappa$ (Petters and Kreidenweis, 2007) is obtained, which is then used to determine the LWC associated with organic components of the aerosol (Guo et al., 2015).

Finally, analysis of 5-day back trajectories of air masses arriving at Finokalia at 1000 and $3000 \mathrm{~m}$ above ground level every $6 \mathrm{~h}$ was conducted with the help of the Hybrid Single Particle Lagrangian Integrated Trajectory Model (HYSPLIT; http://ready.arl.noaa.gov/HYSPLIT.php; Stein et al., 2015).

\subsection{Determination of LWC from nephelometers}

The particle water was inferred using the approach of Guo et al. (2015), where the ratio of the wet and dry $\mathrm{PM}_{1}$ scattering coefficients $\left(\sigma_{\mathrm{sp}}\right)$ measured by the two nephelometers is used. For this, the aerosol hygroscopic growth factor $(f(\mathrm{RH}))$ is calculated according to a wellestablished method based on the two scattering coefficients: $f(\mathrm{RH})=\sigma_{\mathrm{sp}(\text { wet })} / \sigma_{\mathrm{sp}(\mathrm{dry})}$ (e.g., Sheridan, 2002; Magi, 2003; Kim et al., 2006). These scattering coefficients in ambient and dry conditions are proportional to the diameter of average surface $\overline{D_{\mathrm{p}}}$ and the average scattering coefficients $\overline{Q_{\mathrm{s}}}$, so that

$\overline{D_{\text {p,ambient }}}=\overline{D_{\mathrm{p}, \text { dry }}} \sqrt{f(\mathrm{RH}) \overline{Q_{\text {s,dry }}} / \overline{Q_{\text {s,ambient }}}}$.

Assuming that the two average scattering efficiencies are almost equal, LWC is then equal to the difference between ambient and dry particle volume, and by substitution of the dry diameter of average surface

${\overline{D_{\mathrm{p}, \mathrm{dry}}}}^{3}=\frac{m_{\mathrm{p}}}{\left(\frac{\pi}{6}\right) \rho_{\mathrm{p}} N_{\mathrm{t}}}$, where $N_{\mathrm{t}}$ is the total number concentration, $\rho_{\mathrm{p}}$ is the density of dry aerosol, and $m_{\mathrm{p}}$ is the dry mass concentration, we arrive at the simplified expression of

$\mathrm{LWC}=\left[f(\mathrm{RH})^{1.5}-1\right] \frac{m}{\rho_{\mathrm{p}}}$.

The simplification assumption that the dry and ambient scattering efficiencies are almost equal introduces an error into the derived LWC, which based on the detailed analysis of Guo et al. (2015) is of the order of $10 \%$ at $\mathrm{RH}=76.4 \%$ but can reach up to $21 \%$ at $\mathrm{RH}=90 \%$.

For this set of measurements the $\mathrm{PM}_{1}$ dry mass concentration is calculated from the sum of the ACSM constituents combined with the $\mathrm{BC}$ measurements. During the sampling period, the comparison between the sum of ACSM and BC masses and the submicron mass derived from a scanning mobility particle sizer (SMPS; TROPOS-type) is very good ( $y=0.96 x, R^{2}=0.67$ for a period of 2 years; Fig. S3 in the Supplement). Therefore, the bias introduced by ignoring refractory constituents other than $\mathrm{BC}$ is minimal, which is in agreement with size-segregated aerosol chemical composition measurements already conducted at Finokalia (e.g., Koulouri et al., 2008). The particle density, $\rho_{\mathrm{p}}$, was estimated from the particle composition from the ACSM ammonium, organics, and sulfate, using an organic density of $1.35 \mathrm{~g} \mathrm{~cm}^{-3}$ as determined by Lee et al. (2010) for the same site during the summer of 2008 , the density of ammonium sulfate $\left(1.77 \mathrm{~g} \mathrm{~cm}^{-3}\right)$, and the equation

$\rho_{\mathrm{p}}=\left[\frac{x_{\mathrm{a} / \mathrm{s}}}{\rho_{\mathrm{a} / \mathrm{s}}}+\frac{x_{\mathrm{org}}}{\rho_{\mathrm{org}}}\right]^{-1}$,

where $x_{\mathrm{a} / \mathrm{s}}$ is the mass fraction of ammonium sulfate, $x_{\mathrm{org}}$ is the mass fraction of the organics, and $\rho_{\mathrm{a} / \mathrm{s}}$ and $\rho_{\mathrm{org}}$ are the densities of ammonium sulfate and the organics, respectively. It must be noted that nitrate is not taken into account as its concentrations are very close to the limit of detection of the ACSM for the $\mathrm{PM}_{1}$ fraction at the Finokalia site during the studied period. Particle density was calculated to be $1.56 \pm 0.08 \mathrm{~g} \mathrm{~cm}^{-3}$ ( $\left.n=6028\right)$, with aerosol concentration ranging from 1.33 to $16.65 \mu \mathrm{g} \mathrm{m}^{-3}$ and an average value of $5.62 \pm 3 \mu \mathrm{g} \mathrm{m}^{-3}$. The particle water calculated by this method is hereafter referred to as $f(\mathrm{RH})$ _water, with the uncertainty of this calculation being estimated to be $23 \%$ (Guo et al., 2015).

\subsection{LWC and $\mathrm{pH}$ prediction from chemical composition}

The water vapor uptake by aerosol, which establishes an equilibrium for ambient temperature and relative humidity conditions, is influenced by both inorganic and organic components. LWC, therefore, is directly dependent on aerosol chemical composition and meteorological conditions, as well. As proposed by Guo et al. (2015) and explained be- 
low, we calculated the particle water associated with inorganics ( $\left.W_{\text {inorg }}\right)$ and the particle water associated with organics $\left(W_{\text {org }}\right)$. The sum of these two $\left(W_{\text {inorg }}+W_{\text {org }}\right)$, equal to the total-particle water, is then compared to the LWC determined by the two nephelometers.

First, the particle $\mathrm{pH}$ was calculated by the thermodynamic model ISORROPIA-II for the $\mathrm{PM}_{1}$ aerosol fraction. $W_{\text {inorg }}$ was calculated based on a thermodynamic equilibrium between an inorganic aerosol $\left(\mathrm{NH}_{4}-\mathrm{SO}_{4}-\mathrm{NO}_{3}-\mathrm{Cl}-\mathrm{Na}-\mathrm{Ca}-\mathrm{K}-\right.$ $\mathrm{Mg}$-water) and its gas phase precursors. For the current analysis, the inputs to ISORROPIA-II are the inorganic ions measured by the ACSM with a $30 \mathrm{~min}$ time resolution (except for $\mathrm{Cl}$ which is at the detection limit of the instrument at the specific site), the average daily values for $\mathrm{Na}^{+}, \mathrm{Cl}^{-}, \mathrm{Ca}^{2+}$, $\mathrm{K}^{+}$, and $\mathrm{Mg}^{2+}$ determined by ion chromatography analysis of $\mathrm{PM}_{1}$ filters, and RH and $T$ measured by the ambient nephelometer probe. The use of daily values for the macromineral elements obtained from the filter analysis could introduce potential artifacts into the calculation but is believed to be limited as almost $90 \%$ of the fine fraction mass in the area can be attributed to ammonium sulfate and organics (Koulouri et al., 2008; Bougiatioti et al., 2009, 2013).

The contribution of the organic components to particle water $\left(W_{\text {org }}\right)$ was determined from the organic hygroscopicity parameter $\left(\kappa_{\mathrm{org}}\right)$ from the observed CCN activities of the organic fraction (Cerully et al., 2015):

$W_{\text {org }}=\frac{m_{\mathrm{s}}}{\rho_{\mathrm{s}}} \frac{\kappa_{\mathrm{org}}}{\left(\frac{1}{\mathrm{RH}}-1\right)}$,

where $m_{\mathrm{S}}$ and $\rho_{\mathrm{S}}$ are the organic mass concentration from the ACSM and an organic density, respectively, determined as described in Sect. 2.3.

Finally, the particle $\mathrm{pH}$ is calculated by the thermodynamic model ISORROPIA-II (Fountoukis and Nenes, 2007) based on the calculated equilibrium particle hydronium ion concentration in the aerosol. As ISORROPIA-II does not take into account the LWC associated with the organic aerosol, a recalculation of $\mathrm{pH}$ is made by considering the predicted particle hydronium ion concentration per volume of air $\left(H_{\text {air }}^{+}\right)$and the total predicted water $\left(W_{\text {inorg }}+W_{\text {org }}\right)($ Guo et al., 2015):

$\mathrm{pH}=-\log _{10} H_{\mathrm{aq}}^{+}=-\log \frac{1000 H_{\text {air }}^{+}}{W_{\text {org }}+W_{\text {inorg }}}$,

where the modeled concentrations for LWC and $H_{\text {air }}^{+}$are in $\mu \mathrm{g} \mathrm{m}^{-3}, H_{\mathrm{aq}}^{+}\left(\mathrm{mol} \mathrm{L}^{-1}\right)$ is the hydronium concentration in an aqueous solution, and $W_{\text {inorg }}$ and $W_{\text {org }}$ are in $\mu \mathrm{g} \mathrm{m}^{-3}$. ISORROPIA-II has been previously tested and was able to predict the equilibrium partitioning of ammonia and nitric acid to within measurement uncertainty (Nowak et al., 2006; Fountoukis et al., 2009; Hennigan et al., 2015; Guo et al., 2015). Here, ISORROPIA-II was run in the "forward mode" assuming a metastable aerosol state. It should be noted that gas phase measurements of ammonia $\left(\mathrm{NH}_{3(\mathrm{~g})}\right)$ were generally not available for the whole measurement period and the sum of $\mathrm{NH}_{3}$ and $\mathrm{NH}_{4}^{+}$is assumed to be equal to $\mathrm{NH}_{4}^{+}$. Therefore it is expected that the $\mathrm{pH}$ could be underpredicted by at most one unit (Guo et al., 2015; Weber et al., 2016).

To assess the uncertainty in our calculations by not including gas phase $\mathrm{NH}_{3}$, a sensitivity analysis is performed by adding different amounts of $\mathrm{NH}_{3(\mathrm{~g})}$ to the system and quantifying the response in $\mathrm{pH}$. Initial results of ISORROPIA, were compared to results obtained after adding $0.5,1.2,3.2$, and $5 \mu \mathrm{g} \mathrm{m}^{-3}$ of ammonia. The values of 1.2 and $3.2 \mu \mathrm{g} \mathrm{m}^{-3}$ were the median and maximum values, respectively, of the gas phase measurements conducted with the WAD during summer 2014. These values are also within the observed values reported by Guo et al. (2015). A 3-year study conducted at the Finokalia station (Kouvarakis et al., 2001) reported that $\mathrm{NH}_{3(\mathrm{~g})}$ concentrations during summertime have an average of $0.27 \mu \mathrm{g} \mathrm{m}^{-3}$ (range from 0.07 to $0.68 \mu \mathrm{g} \mathrm{m}^{-3}$ ). Thus, a lower value $\left(0.5 \mu \mathrm{g} \mathrm{m}^{-3}\right)$ to represent these measurements was also applied, and finally $5 \mu \mathrm{g} \mathrm{m}^{-3}$ was selected as an extreme value, which is very close to the European critical level for $\mathrm{NH}_{3}$, established to $8 \mu \mathrm{g} \mathrm{m}^{-3}$ as an annual mean (Air Quality Guidelines for Europe, 2000). The results of the sensitivity study are provided in detail in the Supplement and clearly show that neglecting the gas phase $\mathrm{NH}_{3}$ in the calculations leads to an underestimate of around 0.5 units in the $\mathrm{pH}$ (from 1.38 to 1.85 median values) for the $\mathrm{NH}_{3}$ range reported for Finokalia.

The above results are further supported by the partitioning of nitric acid between the condensed $\left(\mathrm{NO}_{3}^{-}\right)$and gas phase $\left(\mathrm{HNO}_{3}\right)$. Assuming ideal solutions for the average conditions during the study period derived from ISORROPIA-II, it is calculated that little nitrate should be present in the aerosol phase when $\mathrm{pH}$ is lower than 3 (Fig. S5 Supplement). Indeed, with an average concentration of nitrates of $0.12 \pm 0.06 \mu \mathrm{g} \mathrm{m}^{-3}$ in the fine mode and the resulting partitioning coefficient of less than 0.2 , it is derived that the maximum value of $\mathrm{pH}$ that can be observed for the current conditions is 2 . This value is in total accordance with the upper limit of $\mathrm{pH}$ of 1.85 derived from the sensitivity analysis presented above.

For days when $\mathrm{NH}_{3(\mathrm{~g})}$ measurements exist (summer 2014), following the same methodology as before, the measured concentrations of $\mathrm{NH}_{3(\mathrm{~g})}$ and predictions by the model are in fairly good agreement. Observed gas phase concentrations have an average of $0.79 \pm 0.27 \mu \mathrm{g} \mathrm{m}^{-3}$, while predicted concentrations have an average of $0.65 \pm 0.32 \mu \mathrm{g} \mathrm{m}^{-3}$. Additionally, we directly compared the $\mathrm{pH}$ and $\mathrm{LWC}$ values derived from ISORROPIA in the forward mode when calculations were initiated with total $\left(\mathrm{NH}_{3}+\mathrm{NH}_{4}^{+}\right)$versus paired results $(n=328)$ for the respective values of $\mathrm{pH}$ and LWC derived when the model is initiated with only particulate phase $\mathrm{NH}_{4}^{+}$. The results show that for the specific periods, the addition of $\mathrm{NH}_{3}$ to the calculations has a minor effect on 


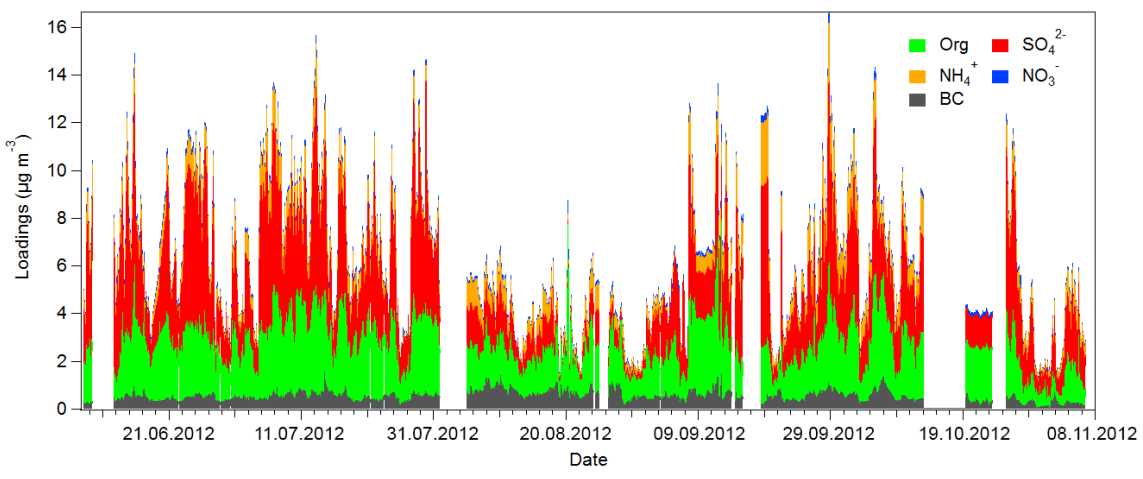

Figure 1. Time series of the main submicron aerosol components at Finokalia, Crete, during the measurement period in 2012.

both $\mathrm{pH}\left(y=0.965 x, R^{2}=0.584\right)$ and $\operatorname{LWC}(y=1.055 x$, $\left.R^{2}=0.993\right)$.

\section{Results and discussion}

\section{1 $\mathrm{PM}_{1}$ chemical composition and $f(\mathrm{RH}) \_$water}

For the measurement period, the average values for the main aerosol constituents were $1.85 \pm 0.94,2.31 \pm 1.61$, $0.81 \pm 0.58$, and $0.52 \pm 0.22 \mu \mathrm{g} \mathrm{m}^{-3}$ for organics, sulfate, ammonium, and $\mathrm{BC}$, respectively. In terms of contribution to the $\mathrm{PM}_{1}$ mass concentration, the two most abundant components of the submicron range were sulfate and organics, with mass fractions of 39.6 and $33.8 \%$, respectively, followed by ammonium $(14.8 \%), \mathrm{BC}(9.3 \%)$, and nitrate $(2.1 \%)$. Chloride has a negligible contribution to the total submicron mass concentration. The time series of the main aerosol constituents and their overall contribution, as measured by the ACSM, are portrayed in Fig. 1. Nevertheless, a fluctuation of $10-20 \%$ in sulfate and/or ammonium concentrations is not expected to be reflected in a $\mathrm{pH}$ change, given the logarithmic scale of the property, which is consistent with the findings of Weber et al. (2016) that $\mathrm{pH}$ has a weak sensitivity to a wide range of $\mathrm{SO}_{4}^{2-}$ and $\mathrm{NH}_{3}$. This is further elaborated by the sensitivity analysis of gas phase ammonia, where, on average, the 5-fold increase in the added amount of $\mathrm{NH}_{3}$ causes a unit change in $\mathrm{pH}$. More details about the ACSM measurements and performance can be found in Stavroulas et al. (2016).

The chemical composition is expected to influence the water content of aerosol, as well. Mean RH and $T$ during the study period were $57 \pm 11 \%$ and $27.4 \pm 3.7^{\circ} \mathrm{C}$. As described in the Sect. 2.3, $f(\mathrm{RH}) \_$water was calculated from the data from the two nephelometers. With the use of Eqs. (1) and (2), we calculated LWC from the nephelometers for the whole measurement period. The average value of $f(\mathrm{RH})$ _water was $2.19 \pm 1.75 \mu \mathrm{g} \mathrm{m}^{-3}$, which according to the dry mass measurements, can contribute on average, up to $33 \%$ of the total submicron mass concentration. We also sought to establish a link between $f(\mathrm{RH})$ and $\mathrm{RH}$, and taking into account all available scattering data $(n=7044)$, the following parameterization has been established:

$$
\begin{aligned}
f(\mathrm{RH}) & =1.067( \pm 0.004) \\
& +1.99( \pm 1.05) 10^{-7} \mathrm{RH}^{3.547( \pm 0.035)} .
\end{aligned}
$$

Based on this, we reconstructed the time series of the hygroscopic growth factors, with a very good correlation between calculated and measured values $\left(y=0.99 x, R^{2}=0.85\right.$; also see the Supplement). This parameterization does not appear to be influenced by changes in the chemical composition. Uncertainties in the RH measurement by the probe are on the order of $5 \%$, while dry and wet aerosol light scattering coefficient measurement uncertainty is on the order of $20 \%$.

\subsection{Inorganic and organic water predictions}

\subsubsection{Inorganic aerosol water}

The thermodynamic model ISORROPIA-II (http://isorropia. eas.gatech.edu; Fountoukis and Nenes, 2007) was used to predict the contribution of inorganic species to LWC. The water attributed to the inorganic component of the aerosol has an average value of $1.77 \pm 1.45 \mu \mathrm{g} \mathrm{m}^{-3}$. The lowest values are observed during August, probably because of the higher temperatures that enhance evaporation of water from the aerosol. The time series for aerosol water associated both with inorganic and organic aerosol components are shown in Fig. 2, where it can be seen that most of the time, the variabilities of the two water components follow each other closely, with water concentrations associated with organics being about $1 / 10(12 \pm 9 \%)$ of those associated with the inorganic aerosol components. 


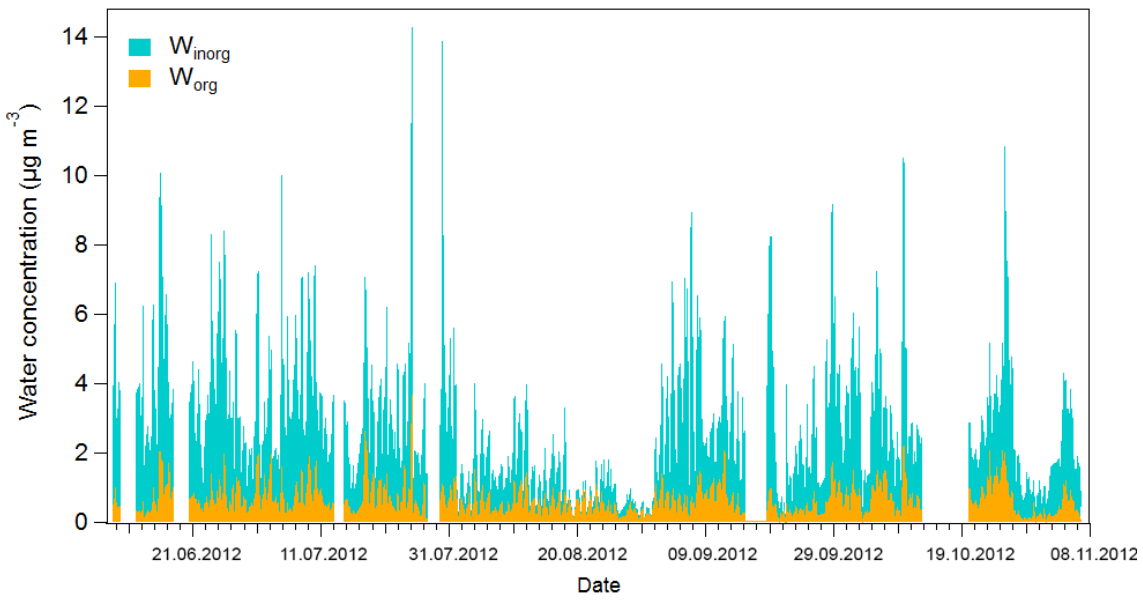

Figure 2. Time series of the two calculated aerosol water components, the water associated with the inorganic ( $\left.W_{\text {inorg }}\right)$ and the organic $\left(W_{\text {org }}\right)$ aerosol components.

\subsubsection{Organics: hygroscopicity and aerosol water}

The contribution of the organic submicron fraction of the aerosol to the particle water was calculated from the combination of the $\mathrm{CCN}$ and chemical composition measurements, as described in Sect. 2.4. Assuming that the cumulative aerosol hygroscopicity can be represented as the sum of contribution of the inorganic (expressed mostly by ammonium sulfate) and organic fraction of the aerosol, the measured hygroscopicity can be calculated by the sum

$\kappa=\varepsilon_{\text {inorg }} \kappa_{\text {inorg }}+\varepsilon_{\text {org }} \kappa_{\text {org }}$,

where $\varepsilon_{j}$ and $\kappa_{j}$ are the volume fraction and hygroscopicity of the inorganic and organic species. Once the aerosol species concentrations are determined, the corresponding volume fractions for ammonium sulfate and organics are calculated, and a set of hygroscopicity parameter equations is produced. As mentioned in the Sect. 2.2, hygroscopicity parameters for $60,80,100$, and $120 \mathrm{~nm}$ particles are measured. In a previous CCN study at the same site (Bougiatioti et al., 2011), it was shown that from many different particle sizes, the characteristic hygroscopicity parameter $\kappa^{*}$ of the $100 \mathrm{~nm}$ particles was the closest one to the $\kappa$ determined by $\mathrm{PM}_{1}$ filter measurements. Therefore, we created two different sets of $\kappa$ equations along with the volume fractions to calculate the total $\kappa^{*}$ and one for the 100 and another one for the $120 \mathrm{~nm}$. With the subsequent application of multivariate regression analysis to the set of $n=2429$ and 1801 equations (for 100 and $120 \mathrm{~nm}$, respectively), $\kappa_{\text {org }}$ is determined to be $0.28 \pm 0.01$ based on the $\kappa_{-} 100 \mathrm{~nm}$ and $0.24 \pm 0.01$ based on the $\kappa_{-} 120 \mathrm{~nm}$. The average value of 0.26 is used in Eq. (5) to calculate the time series of $W_{\text {org. }}$. The average value $W_{\text {org }}$ was thus found to be $0.56 \pm 0.37 \mu \mathrm{g} \mathrm{m}^{-3}$, which constitutes on average $\sim 27.5 \%$ of the calculated $f(\mathrm{RH})$ _water. The overall uncertainty of this calculation is estimated by Guo et al. (2015) to be around
$30 \%$. That study for the southeastern United States of America found a higher contribution of organic species (on average $35 \%$ ) to the total water, which can be explained by the dominance of organics in the submicron range aerosol, with an average mass fraction of $67 \%$.

\subsubsection{Aerosol water}

Aerosol water is the sum of $W_{\text {org }}+W_{\text {inorg }}$, determined as previously explained. This can be further compared with the time series of the $f(\mathrm{RH})$ _water deduced from concurrent observations by the two nephelometers (Sect. 2.3), independent of the aerosol water calculated as here explained. The particle water predicted from the sum of the organic and inorganic contributions to the water agrees very well with the water measured by the nephelometers (Fig. 3). More specifically, the total predicted water is highly correlated and on average within $10 \%$ of the measured water, with slope $=0.92$ and $R^{2}=0.8$ for the whole measurement period $(n=5201$ points).

The diurnal variability of the calculated water components, along with the total measured water, ambient $T$, and $\mathrm{RH}$, is shown in Fig. 4. It must be noted at this point that the diurnal variability presented corresponds to the entire period of the study, and this pattern seems to be independent of the geographical sector and/or source region, based on the back trajectory analysis. The diurnal variability of aerosols from different sources, further presented in Sect. 3.4, has been explicitly studied and found not to differ significantly; therefore, the total diurnal variability was selected as being representative of the whole measurement period. Predicted and measured aerosol LWC diurnal variabilities are in very good agreement. As expected, the highest LWC values are observed during nighttime, when RH is also at its maximum, resulting in significant water uptake. $W_{\text {org }}$ shows a significant diurnal variability, with morning and afternoon average 


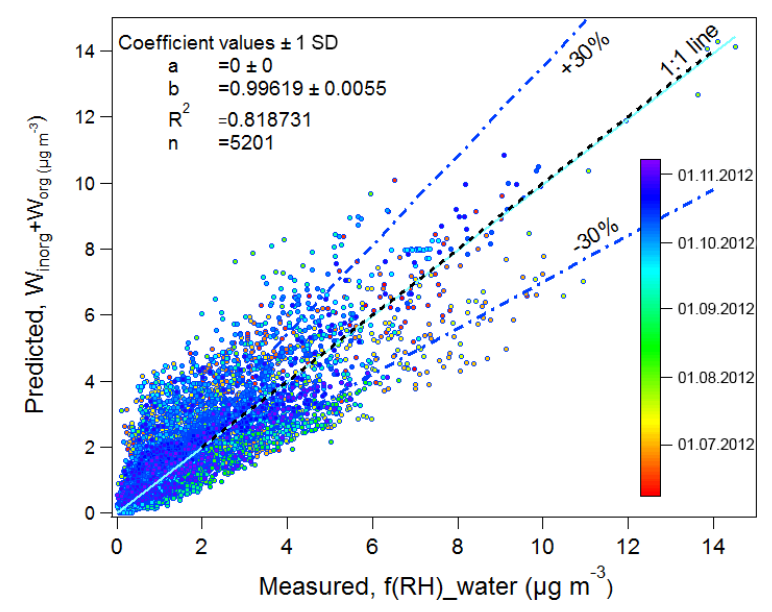

Figure 3. Correlation between calculated and measured LWC of aerosol.

mass concentrations being 10-15 times lower than nighttime ones. Thus, during daytime, $W_{\text {inorg }}$ is the main component of particle water as the average values for the predicted water $\left(W_{\text {org }}+W_{\text {inorg }}\right)$ are very close to the ones of the inorganic water alone. On the other hand, during nighttime, the two averages start to diverge and this could be attributed to the higher contribution of organic water during nighttime, when the photochemical activity and temperature are minimum and RH high.

\subsection{Aerosol pH}

The predicted $\mathrm{pH}$ for the aerosols collected at Finokalia during the studied period was highly acidic with an average value of $1.25 \pm 1.14$ (median 1.51) and varying between -0.97 and 3.75 . $\mathrm{pH}$ varied by almost 1 unit throughout the day. This can be translated into an almost 10-fold increase in the $H_{\text {air }}^{+} /$LWC ratio from early morning to midday and into a lesser increase during the early night. This significant variation in $\mathrm{pH}$ can be partially explained by the diurnal variation of $\mathrm{H}^{+}$and its increase, which coincides temporally with the decrease in $\mathrm{pH}$ (Fig. 5), and by the reduction in aerosol water (LWC) during daytime compared to the higher LWC during nighttime (Fig. 4). This implies that the diurnal variability of $\mathrm{pH}$ is mostly driven by the reduction in aerosol water during daytime compared to the higher aerosol water during nighttime.

When studying the diurnal variability of $\mathrm{pH}$ for the different sources and geographical sectors (Supplement), one may find that $\mathrm{pH}$ differs depending on the source and origin of the air masses. Air masses from northwestern and northeastern Europe and Turkey, as well as from the Greek mainland, do not exhibit significant diurnal variability. When no distinction is made between source regions, the pattern of the overall $\mathrm{pH}$ variability with a drop in $\mathrm{pH}$ values during midday as presented in Fig. 5 is similar to the diurnal variability of

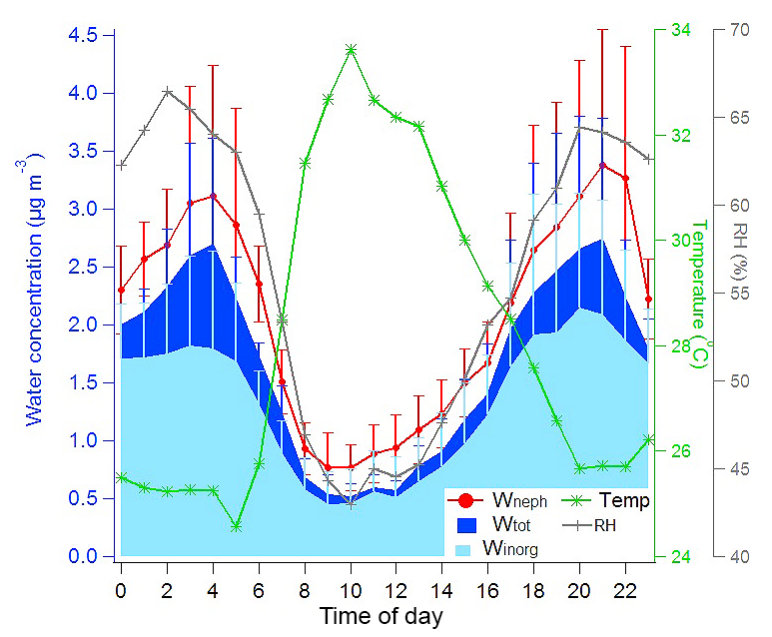

Figure 4. Diurnal profiles of predicted and measured water, along with measured $\mathrm{RH}$ and $T$. Average hourly averages and standard deviations plotted as error bars in local time are shown.

$\mathrm{pH}$ for air masses influenced by mineral dust (coming from the $\mathrm{SW}$ ) and by biomass burning, but with $\mathrm{pH}$ values from biomass burning being 1-1.5 units higher. Nevertheless, the mean $\mathrm{pH}$ values for each of the source regions is very close to the overall mean $\mathrm{pH}$ value when no distinction of origin is made.

Furthermore, accounting only for the water associated with the inorganic aerosol component, particle water is underestimated by around $9 \%$, thus resulting in a slightly lower $\mathrm{pH}$ (more acidic) by $0.07-0.38$ units of $\mathrm{pH}$ (Fig. 6a). As seen in Sect. 3.2, $W_{\text {org }}$ is on average $27.5 \%$ of the total water, as a result the $\mathrm{pH}$ increases by 0.14 units when the organic water is included (Fig. 6a). When the contribution of organic water is taken into account, the recalculation of $\mathrm{pH}$ gives an average value of $1.38 \pm 1.11$ (median 1.65). The $\mathrm{pH}$ calculated by ISORROPIA-II correlates very well with the $\mathrm{pH}$ corrected using Eq. (6) for the inclusion of the organic water $\left(W_{\text {org }}+W_{\text {inorg }}\right)\left(R^{2}=0.98\right.$, Fig. 6b). Subsequently, if organic mass and organic hygroscopicity data are not available, ISORROPIA-II solely based on inorganic composition data will provide an adequate estimate of both $H_{\text {air }}^{+}$and $W_{\text {inorg }}$ and thus of $\mathrm{pH}$.

\subsection{Aerosol water and pH based on aerosol fraction and source region}

Apart from the time-resolved aerosol water and $\mathrm{pH}$ calculations for the submicron aerosol fraction, aerosol water and $\mathrm{pH}$ were also calculated based on the daily $\mathrm{PM}_{10}$ filter chemical composition analysis. It should be noted at this point that there is a strong link between aerosol $\mathrm{pH}$ and aerosol size distribution due to the chemical composition changes in the aerosol size. For $\mathrm{PM}_{1}$, which is in equilibrium, the chemical composition is determined by high time resolution 

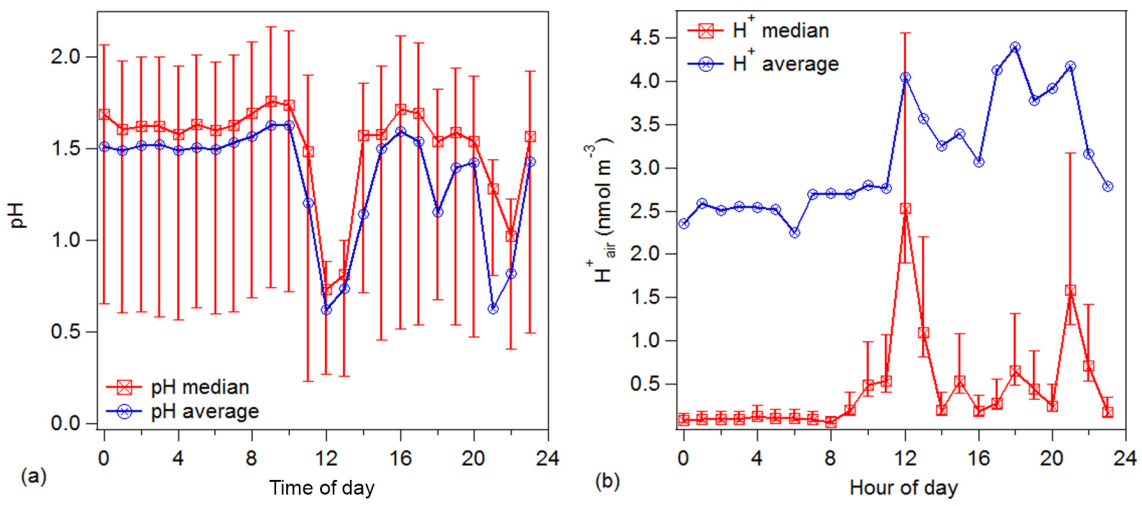

Figure 5. Diurnal profile of $\mathrm{pH}$ (a) and $\mathrm{H}^{+}$(b) calculated based on total predicted water and hydronium concentrations predicted by ISORROPIA-II. Average and median (with 25 and $75 \%$ quantiles) values are provided.

Table 1. Average values of water content (total and organic) and $\mathrm{pH}$ with standard deviation and median values in parentheses.

\begin{tabular}{|c|c|c|c|c|c|c|}
\hline \multirow[b]{2}{*}{ Source or region } & \multicolumn{3}{|c|}{$\mathrm{PM}_{1}$} & \multicolumn{3}{|c|}{$\mathrm{PM}_{1} / \mathrm{PM}_{10}$} \\
\hline & water $_{\text {tot }}\left(\mu \mathrm{g} \mathrm{m}^{-3}\right)$ & water $_{\text {org }}\left(\mu \mathrm{g} \mathrm{m}^{-3}\right)$ & $\mathrm{pH}$ & mass & water $_{\text {tot }}$ & $\mathrm{pH}$ \\
\hline $\begin{array}{l}\text { Biomass burning } \\
(n=7)\end{array}$ & $\begin{array}{l}1.33 \pm 1.22 \\
(1.56)\end{array}$ & $\begin{array}{l}0.37 \pm 0.33 \\
(0.39)\end{array}$ & $\begin{array}{l}2.77 \pm 0.88 \\
\quad(2.67)\end{array}$ & $\begin{array}{l}0.48 \pm 0.16 \\
\quad(0.47)\end{array}$ & $\begin{array}{l}0.08 \pm 0.09 \\
\quad(0.05)\end{array}$ & $\begin{array}{l}0.89 \pm 0.2 \\
\quad(0.93)\end{array}$ \\
\hline $\begin{array}{l}\text { Istanbul \& Black Sea } \\
(n=7)\end{array}$ & $\begin{array}{l}1.72 \pm 0.54 \\
\quad(1.21)\end{array}$ & $\begin{array}{l}0.81 \pm 0.34 \\
\quad(0.75)\end{array}$ & $\begin{array}{l}1.92 \pm 0.24 \\
\quad(2.00)\end{array}$ & $\begin{array}{l}0.72 \pm 0.09 \\
\quad(0.69)\end{array}$ & $\begin{array}{l}0.33 \pm 0.21 \\
\quad(0.26)\end{array}$ & $\begin{array}{l}0.94 \pm 0.67 \\
\quad(0.88)\end{array}$ \\
\hline $\begin{array}{l}\text { Continental Europe } \\
(n=9)\end{array}$ & $\begin{array}{l}1.52 \pm 0.64 \\
(1.32)\end{array}$ & $\begin{array}{l}0.48 \pm 0.34 \\
(0.47)\end{array}$ & $\begin{array}{l}1.30 \pm 0.19 \\
(1.26)\end{array}$ & $\begin{array}{l}0.60 \pm 0.18 \\
\quad(0.64)\end{array}$ & $\begin{array}{l}0.31 \pm 0.17 \\
\quad(0.28)\end{array}$ & $\begin{array}{l}0.58 \pm 0.47 \\
\quad(0.50)\end{array}$ \\
\hline $\begin{array}{l}\text { Dust } \\
(n=7)\end{array}$ & $\begin{array}{l}2.48 \pm 0.54 \\
(2.44)\end{array}$ & $\begin{array}{l}0.48 \pm 0.22 \\
(0.39)\end{array}$ & $\begin{array}{l}1.48 \pm 0.44 \\
\quad(1.59)\end{array}$ & $\begin{array}{l}0.34 \pm 0.08 \\
\quad(0.38)\end{array}$ & $\begin{array}{l}0.39 \pm 0.08 \\
(0.29)\end{array}$ & $\begin{array}{l}0.30 \pm 0.17 \\
\quad(0.25)\end{array}$ \\
\hline $\begin{array}{l}\text { Marine } \\
(n=7)\end{array}$ & $\begin{array}{l}2.38 \pm 1.24 \\
\quad(1.91)\end{array}$ & $\begin{array}{l}0.37 \pm 0.17 \\
\quad(0.34)\end{array}$ & $\begin{array}{l}0.44 \pm 0.67 \\
(0.43)\end{array}$ & $\begin{array}{l}0.58 \pm 0.27 \\
(0.57)\end{array}$ & $\begin{array}{l}0.83 \pm 0.6 \\
\quad(0.70)\end{array}$ & $\begin{array}{l}0.06 \pm 0.19 \\
\quad(0.05)\end{array}$ \\
\hline
\end{tabular}

measurements, which leads to a higher accuracy in the $\mathrm{pH}$ calculations. On the other hand, as $\mathrm{PM}_{10}$ particles are not in equilibrium, the respective acidity results are subject to biases and are less quantitative than the submicron results. For comparison purposes the corresponding $\mathrm{PM}_{1}$ measurements, based on ACSM and the respective $\mathrm{PM}_{1}$ ionic concentrations for cations such as $\mathrm{Na}^{+}, \mathrm{Ca}^{2+}$, and $\mathrm{Mg}^{2+}$, corresponding to the fine fraction, have also been averaged to daily values. Characteristic source regions and sources were subsequently selected based on back trajectory analysis and chemical tracers. Furthermore, biomass burning events have been identified based on source apportionment of $\mathrm{BC}$ and positive matrix factorization (PMF) analysis of the organic mass spectra obtained from the ACSM as detailed in Bougiatioti et al. (2014). Dust events were identified by back trajectory analysis of the air masses, originating from northwestern Africa and confirmed as containing large amounts of particulate matter (45-55 $\mathrm{\mu g} \mathrm{m}^{-3}$ in $\mathrm{PM}_{10}$ mass) and high concentrations of crustal ions, such as $\mathrm{Ca}^{2+}$ (median concentration during dust events of $1.8 \mu \mathrm{g} \mathrm{m}^{-3}$ versus $0.6 \mu \mathrm{g} \mathrm{m}^{-3}$ for the rest of the days). The main measured and calculated parameters are presented in Table 1.

It can be seen that, in general, for anthropogenically influenced air masses (e.g., from Istanbul, the Black Sea, and continental Europe), aerosol mass resides mainly (60-70\%) in the submicron aerosol and thus the submicron fraction seems also to drive the $\mathrm{pH}$ of $\mathrm{PM}_{10}$, while most of the aerosol water $(\sim 70 \%)$ is present in the coarse fraction. Biomass burning exhibits the highest values of $\mathrm{pH}$ in the submicron fraction and the lowest values in total water mass concentration. Interestingly enough, the value of 2.77 for biomass burning $\mathrm{pH}$ is well above the value of 2 , which favors the partitioning of nitrate to the aerosol phase (e.g., Meskhidze et al., 2003) The correlation observed during fire events between biomass burning organic aerosol and particulate nitrates (e.g., Bougiatioti et al., 2014) may be explained by these higher pH levels, rather than just high levels of nitric acid and/or ammonia. As found in the literature, higher $\mathrm{pH}$ levels of biomass burning aerosol could possibly be associated with higher concentrations of non-sea-salt potassium, which as an ionic species 

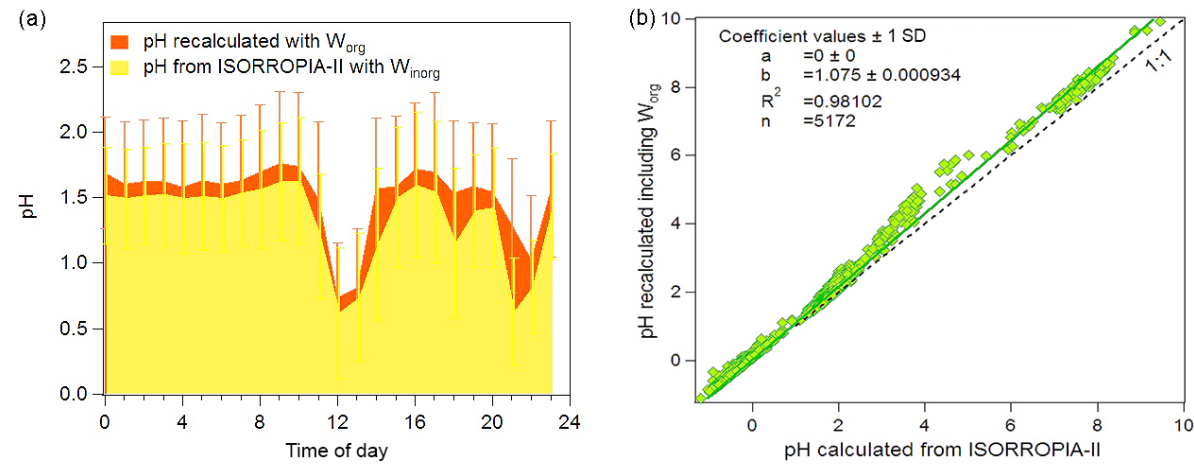

Figure 6. Panel (a): diurnal variability of $\mathrm{pH}$ based on total predicted water (orange, using both $W_{\text {org }}$ and $W_{\text {inorg }}$ ) and only the inorganic water (yellow, using only $W_{\text {inorg }}$ ); average hourly values and standard deviation in the form of error bars are provided. Panel (b): comparison between the $\mathrm{pH}$ predicted by ISORROPIA-II based on inorganic aerosol composition and that recalculated including also the organic component.

influences the $\mathrm{pH}$ (Zhang et al., 2015), rendering aerosol less acidic. Based on the calculated ratios for $\mathrm{pH}$ and particle water, it can be derived that the ions that set the bulk $\mathrm{pH}$ are mostly driven by the fine mode; the LWC however is associated mostly with the supermicron aerosol mass. Hygroscopic sea salt components are also found in the coarse mode, which can explain the larger contribution of $\mathrm{PM}_{10}$ total water, while the submicron fraction may be composed mostly of less hygroscopic, organic components (Bougiatioti et al., 2015). Even though strong dust events were lacking during the study period, numerous weaker events were captured. Through these events aerosol mass, total water, and $\mathrm{pH}$ are mostly driven by the coarse aerosol fraction. This is consistent with the findings of Koulouri et al. (2008) that most $(86 \%)$ of the mass of crustal components were found in coarse particles. In terms of mass concentration, the two natural sources, namely air masses of marine and dust origin, contain the largest amounts of total submicron water. Even though total water exhibits the highest mass concentrations for the specific sources, the relative contribution of organic water to the submicron fraction is the lowest $(16 \%$ for dust and $17 \%$ for marine, based on the median values). For the two natural sources, the ratio of submicron $\mathrm{pH}$ and calculated $\mathrm{pH}$ for the $\mathrm{PM}_{10}$ fraction is the lowest observed (Table 1), namely $30 \pm 17 \%$ (median $25 \%$ ) and $6 \pm 19 \%$ (median $5 \%$ ).

\subsection{Atmospheric implications}

The $\mathrm{pH}$ values for submicron and $\mathrm{PM}_{10}$ fractions is also expected to affect many processes, such as the solubility and therefore the bioavailability of nutrients and especially phosphorus $(\mathrm{P})$ and iron $(\mathrm{Fe})$. This is of crucial importance for seas such as the eastern Mediterranean for which primary productivity is P limited (Krom et al., 1991). One of the striking results of the aerosol $\mathrm{pH}$ calculations (presented in Table 1) is that with the exception of biomass burning, the $\mathrm{pH}$ of all submicron aerosols including those originating from desert dust is highly acidic, with values typically below 2 . Although the nutrient flux from the fine mode is certainly smaller than in the coarse mode, it can be transported much further away from source regions before deposition and be considerably more acidified (hence bioavailable). Based on published literature (Nenes et al., 2011; Meskhidze et al., 2003), under acidic conditions similar to the derived $\mathrm{pH}$ aerosol values, the acid-mobilized dissolution of such nutrients is expected to be of great importance.

By analyzing $\mathrm{PM}_{10}$ aerosols collected in Greece (Finokalia) and Turkey (Erdemli) for dissolved inorganic (DIP) and total (TP) phosphorus levels, Markaki et al. (2003) have shown that although the SW sector, corresponding to the Sahara, presented TIP levels higher by a factor of 2 than the European (NE or NW) sectors, the lowest values for the DIP / TIP ratio are associated with the SE and SW sectors and the highest with the $\mathrm{N}$ sectors (with a difference of almost a factor of 2). The explanation for this behavior is given by the ratio of $\mathrm{pH}$ in $\mathrm{PM}_{1}$ and $\mathrm{PM}_{10}$ aerosols that is presented in Table 1 . In aerosols from the NW sector only a very small difference in $\mathrm{pH}$ between the two fractions is observed, while in desert aerosols the large amount of dust present in the coarse mode highly influences $\mathrm{pH}$ of $\mathrm{PM}_{10}$ leading to a significant decrease in acidity and thus $\mathrm{P}$ solubility. However, as dust events can transport large amounts of $\mathrm{P}$ (up to a factor of 3 higher than in air masses coming from Europe), any future change in the $\mathrm{PM}_{1} / \mathrm{PM}_{10}$ ratio caused by dust events will significantly influence $\mathrm{P}$ availability and deposition to the eastern Mediterranean sea and thus its productivity.

\section{Conclusion}

Using the aerosol chemical composition measurements by ACSM, thermodynamic models, such as ISORROPIA-II, and CCN measurements, we calculated the particle water associated with both inorganic $\left(W_{\text {inorg }}\right)$ and organic $\left(W_{\text {org }}\right)$ 
aerosol components. The sum of these two $\left(W_{\text {inorg }}+W_{\text {org }}\right)$ equal to the total-particle water, is then compared to the LWC, determined by the two nephelometers operating in dry and wet mode. Predicted aerosol water was compared to LWC determined from ambient versus dry light scattering coefficients. At Finokalia the sum of $W_{\text {inorg }}$ and $W_{\text {org }}$ was highly correlated and in close agreement with the measured LWC (on average within $10 \%$ ), with slope $=0.92$ and $R^{2}=$ 0.8 for the whole measurement period ( $n=5201$ points). As expected, the highest fine aerosol water values are observed during nighttime, when $\mathrm{RH}$ is also at its maximum, resulting in significant water uptake. $W_{\text {org }}$ shows a significant diurnal variability, with morning and afternoon average mass concentrations being 10-15 times lower than nighttime concentrations. Thus, during daytime, $W_{\text {inorg }}$ is the main form of particle water as the average values for the predicted water $\left(W_{\text {org }}+W_{\text {inorg }}\right)$ are very close to the ones of the inorganic water alone. On the other hand, the contribution of organic water to the total aerosol water increases, becoming significant during nighttime, when the photochemical activity and temperature are minimal. The average concentration of total aerosol water was found to be $2.19 \pm 1.75 \mu \mathrm{g} \mathrm{m}^{-3}$, which, according to the dry mass measurements, can contribute on average up to $33 \%$ of the total submicron mass concentration. The average aerosol water associated with organics, $W_{\text {org }}$, was found to be $0.56 \pm 0.37 \mu \mathrm{g} \mathrm{m}^{-3}$, which constitutes about $27.5 \%$ of the total calculated water. The overall uncertainty of this calculation is estimated to be around $30 \%$.

Based on aerosol water, particle $\mathrm{pH}$ is also calculated, a parameter which is very important for the atmospheric implications of aerosols but is difficult to measure directly. In the eastern Mediterranean during the studied period, aerosol $\mathrm{pH}$ varied from 0.5 to 2.8 , indicating that the aerosol was highly acidic throughout the period. Biomass burning aerosol presented the highest values of $\mathrm{pH}$ in the submicron fraction and the lowest values in total water mass concentration. Interestingly enough, the value of 2.8 for the biomass burning $\mathrm{pH}$ is well above the value of 2 , which is a lower limit for the occurrence of nitrate condensation. The correlation, which has been observed during fire events between biomass burning organic aerosol and particulate nitrates, may be explained by these $\mathrm{pH}$ levels, which favor nitrate condensation. It can be seen that, in general, for anthropogenically influenced air masses (e.g., from Istanbul, the Black Sea, and continental Europe), aerosol mass resides mainly in the submicron aerosol (60-70\%) and thus the submicron fraction seems also to drive the $\mathrm{pH}$ of $\mathrm{PM}_{10}$, while most of the aerosol water $(\sim 70 \%)$ is present in the coarse fraction. $\mathrm{pH}$ is driven by the fine mode, while the great majority of the aerosol water is present in the coarse mode. This may be due to the important contributions of the hygroscopic sea salt components in the coarse mode and of the less hygroscopic organics in the fine mode.

In terms of mass concentration, the air masses affected by the two natural sources, namely marine and dust, contain the largest amounts of total submicron water. Even though total water exhibits the highest mass concentrations for the specific sources, the relative contribution of organic water to the submicron fraction is the lowest $(\sim 19 \%$ for dust and $\sim 15.5 \%$ for marine). For these two natural sources, the ratio of submicron $\mathrm{pH}$ and calculated $\mathrm{pH}$ for the $\mathrm{PM}_{10}$ fraction is the lowest observed, i.e., $30 \pm 17 \%$ (median $25 \%$ ) and $6 \pm 19 \%$ (median $5 \%$ ).

The low $\mathrm{pH}$ values observed during the studied period in the submicron mode and independently of air mass origin could have significant implications for nutrient availability and especially for $\mathrm{P}$ solubility, which is the nutrient limiting sea water productivity in the eastern Mediterranean.

\section{The Supplement related to this article is available online at doi:10.5194/acp-16-4579-2016-supplement.}

Acknowledgements. This research has been co-financed by the European Union (European Social Fund - ESF) and Greek national funds through the Operational Program "Education and Lifelong Learning" of the National Strategic Reference Framework (NSRF) - Research Funding Program ARISTEIA I - PANOPLY. The authors gratefully acknowledge the NOAA Air Resources Laboratory (ARL) for the provision of the HYSPLIT transport and dispersion model and the READY website (http://www.ready.noaa.gov) used in this publication.

Edited by: F. Dentener

\section{References}

Bardouki, H., Liakakou, H., Economou, C., Sciare, J., Smolik, J., Zdimal, V., Eleftheriadis, K., Lazaridis, M., Dye, C., and Mihalopoulos, N.: Chemical composition of size-resolved atmospheric aerosols in the eastern Mediterranean during summer and winter, Atmos. Environ., 37, 195-208, 2003.

Berner, A. and Lürzer, C.: Mass size distributions of traffic aerosols in Vienna, J. Phys. Chem., 84, 2079-2083, doi:10.1021/j100453a016, 1980.

Bougiatioti, A., Fountoukis, C., Kalivitis, N., Pandis, S. N., Nenes, A., and Mihalopoulos, N.: Cloud condensation nuclei measurements in the marine boundary layer of the Eastern Mediterranean: CCN closure and droplet growth kinetics, Atmos. Chem. Phys., 9, 7053-7066, doi:10.5194/acp-9-7053-2009, 2009.

Bougiatioti, A., Nenes, A., Fountoukis, C., Kalivitis, N., Pandis, S. N., and Mihalopoulos, N.: Size-resolved CCN distributions and activation kinetics of aged continental and marine aerosol, Atmos. Chem. Phys., 11, 8791-8808, doi:10.5194/acp-11-87912011, 2011.

Bougiatioti, A., Zarmpas, P., Koulouri, E., Antoniou, M., Theodosi, C., Kouvarakis G., Saarikoski, S., Mäkelä, T., Hillamo, R., and Mihalopoulos, N.: Organic, elemental and water-soluble organic carbon in size segregated aerosols, in the marine boundary layer 
of the Eastern Mediterranean, Atmos. Environ., 64, 251-262, 2013.

Bougiatioti, A., Stavroulas, I., Kostenidou, E., Zarmpas, P., Theodosi, C., Kouvarakis, G., Canonaco, F., Prévôt, A. S. H., Nenes, A., Pandis, S. N., and Mihalopoulos, N.: Processing of biomassburning aerosol in the eastern Mediterranean during summertime, Atmos. Chem. Phys., 14, 4793-4807, doi:10.5194/acp-144793-2014, 2014.

Bougiatioti, A., Bezantakos, S., Stavroulas, I., Kalivitis, N., Kokkalis, P., Biskos, G., Mihalopoulos, N., Papayannis, A., and Nenes, A.: Influence of biomass burning on $\mathrm{CCN}$ number and hygroscopicity during summertime in the eastern Mediterranean, Atmos. Chem. Phys. Discuss., 15, 21539-21582, doi:10.5194/acpd-15-21539-2015, 2015.

Carlton, A. G. and Turpin, B. J.: Particle partitioning potential of organic compounds is highest in the Eastern US and driven by anthropogenic water, Atmos. Chem. Phys., 13, 10203-10214, doi:10.5194/acp-13-10203-2013, 2013.

Cerully, K. M., Bougiatioti, A., Hite Jr., J. R., Guo, H., Xu, L., Ng, N. L., Weber, R., and Nenes, A.: On the link between hygroscopicity, volatility, and oxidation state of ambient and water-soluble aerosols in the southeastern United States, Atmos. Chem. Phys., 15, 8679-8694, doi:10.5194/acp-15-8679-2015, 2015.

Eddingsaas, N. C., VanderVelde, D. G., and Wennberg, P. O.: Kinetics and Products of the Acid-Catalyzed Ring-Opening of Atmospherically Relevant Butyl Epoxy Alcohols, J. Phys. Chem. A, 114, 8106-8113, doi:10.1021/Jp103907c, 2010.

Fountoukis, C. and Nenes, A.: ISORROPIA II: a computationally efficient thermodynamic equilibrium model for $\mathrm{K}^{+}$. $\mathrm{Ca}^{2+}-\mathrm{Mg}^{2+}-\mathrm{NH}_{4}^{+}-\mathrm{Na}^{+}-\mathrm{SO}_{4}^{2-}-\mathrm{NO}_{3}^{-}-\mathrm{Cl}^{-}-\mathrm{H}_{2} \mathrm{O}$ aerosols, Atmos. Chem. Phys., 7, 4639-4659, doi:10.5194/acp-7-4639-2007, 2007.

Fountoukis, C., Nenes, A., Sullivan, A., Weber, R., Van Reken, T., Fischer, M., Matías, E., Moya, M., Farmer, D., and Cohen, R. C.: Thermodynamic characterization of Mexico City aerosol during MILAGRO 2006, Atmos. Chem. Phys., 9, 2141-2156, doi:10.5194/acp-9-2141-2009, 2009.

Guo, H., Xu, L., Bougiatioti, A., Cerully, K. M., Capps, S. L., Hite Jr., J. R., Carlton, A. G., Lee, S.-H., Bergin, M. H., Ng, N. L., Nenes, A., and Weber, R. J.: Fine-particle water and $\mathrm{pH}$ in the southeastern United States, Atmos. Chem. Phys., 15, 5211-5228, doi:10.5194/acp-15-5211-2015, 2015

Hennigan, C. J., Izumi, J., Sullivan, A. P., Weber, R. J., and Nenes, A.: A critical evaluation of proxy methods used to estimate the acidity of atmospheric particles, Atmos. Chem. Phys., 15, 27752790, doi:10.5194/acp-15-2775-2015, 2015.

Jickells, T. D., An, Z. S., Andersen, K. K., Baker, A. R., Bergametti, G., Brooks, N., Cao, J. J., Boyd, P. W., Duce, R. A., Hunter, K. A., Kawahata, H., Kubilay, N., laRoche, J., Liss, P. S., Mahowald, N., Prospero, J. M., Ridgwell, A. J., Tegen, I., and Torres, R.: Global iron connections between desert dust, ocean biogeochemistry, and climate, Science, 308, 67-71, 2005.

Keene, W. C., Pszenny, A. A. P., Maben, J. R., and Sander, R.: Variation of marine aerosol acidity with particle size, Geophys. Res. Lett., 29, 5-1-5-4, doi:10.1029/2001GL013881, 2002.

Keene, W. C., Pszenny, A. A. P., Maben, J. R., Stevenson, E., and Wall, A.: Closure evaluation of size-resolved aerosol $\mathrm{pH}$ in the New England coastal atmosphere during summer, J. Geophys. Res., 109, D23307, doi:10.1029/2004JD004801, 2004.
Khlystov, A., Stanier, C. O., Takahama, S., and Pandis, S. N.: Water content of ambient aerosol during the Pittsburgh Air Quality Study, J. Geophys. Res.-Atmos., 110, D07S10, doi:10.1029/2004JD004651, 2005.

Kim, J., Yoon, S.-C., Jefferson, A., and Kim, S.-W.: Aerosol hygroscopic properties during Asian dust, pollution, and biomass burning episodes at Gosan, Korea in April 2001, Atmos. Environ., 40, 1550-1560, doi:10.1016/j.atmosenv.2005.10.044, 2006.

Koulouri, E., Saarikoski, S., Theodosi, C., Markaki, Z., Gerasopoulos, E., Kouvarakis, G., Mäkelä, T., Hillamo, R., and Mihalopoulos, N.: Chemical composition and sources of fine and coarse aerosol particles in the Eastern Mediterranean, Atmos. Environ. 42, 6542-9550, 2008.

Kouvarakis, G. Mihalopoulos, N., Tselepides, T., and Stavrakakis, S.: On the importance of atmospheric nitrogen inputs on the productivity of Easter Mediterranean, Global Biochem. Cy., 15, 805-818, 2001.

Krishnamurthy, A., Moore, J. K., Mahowald, N., Luo, C., and Zender, C. S.: Impacts of atmospheric nutrient inputs on marine biogeochemistry, J. Geophys. Res., 115, G01006, doi:10.1029/2009JG001115, 2010.

Krom, M. D., Kress, N., Brenner, S., and Gordon, L. I.: Phosphorus limitation of primary productivity in the eastern Mediterranean Sea, Limnol. Oceanogr., 36, 424-432, 1991.

Lee, T., Sullivan, A. P., Mack, L., Jimenez, J. L., Kreidenweis, S. M., Onasch, T. B., Worsnop, D. R., Malm, W., Wold, C. E., Hao, W. M., and Collett, J. L.: Variation of chemical smoke marker emissions during flaming vs. smoldering phases of laboratory open burning of wildland fuels, Aerosol Sci. Tech., 44, 1-5, doi:10.1080/02786826.2010.499884, 2010.

Liao, H. and Seinfeld, J. H.: Global impacts of gas-phase chemistry aerosol interactions on direct radiative forcing by anthropogenic aerosols and ozone, J. Geophys. Res.-Atmos., 110, D18208, doi:10.1029/2005jd005907, 2005.

Magi, B. I.: Effects of humidity on aerosols in southern Africa during the biomass burning season, J. Geophys. Res., 108, 8495, doi:10.1029/2002jd002144, 2003.

Mahowald, N., Jickells, T. D., Baker, A. R., Artaxo, P., BenitezNelson, C. R., Bergametti, J., Bond, T. C., Chen, Y., Cohen, D. D., Herut, B., Kubilay, N., Losno, R., Luo, C., Maenhaut, W., McGee, K. A., Okin, G. S., Siefert, R. L., and Tsukuda, S.: Global distribution of atmospheric phosphorus sources, concentrations and deposition rates, and anthropogenic impacts, Global Biogeochem. Cy., 22, GB4026, doi:10.1029/2008GB003240, 2008.

Mahowald, N. M., Engelstaedter, S., Luo, C., Sealy, A., Artaxo, P., Benitez-Nelson, C., Bonnet, S., Chen, Y., Chuang, P. Y., Cohen, D. D., Dulac, F., Herut, B., Johansen, A. M., Kubilay, N., Losno, R., Maenhaut, W., Paytan, A., Prospero, J. M., Shank, L. M., and Siefert, R. L.: Atmospheric iron deposition: Global distribution, variability, and human perturbations, Annu. Rev. Mater. Sci., 1, 245-278, doi:10.1146/annurev.marine.010908.163727, 2009.

Markaki, Z., Oikonomou, K., Kocak, M., Kouvarakis, G., Chaniotaki, A., Kubilay, N., and Mihalopoulos, N.: Atmospheric deposition of inorganic phosphorus in the Levantine Basin, Eastern Mediterranean: Spatial, temporal variability and its role on the productivity of the Eastern Mediterranean Sea, Limnol. Oceanogr., 48, 1557-1568, 2003. 
Meskhidze, N., Chameides, W. L., Nenes, A., and Chen, G.: Iron mobilization in mineral dust: Can anthropogenic $\mathrm{SO}_{2}$ emissions affect ocean productivity?, Geophys. Res. Lett., 30, 2085, doi:10.1029/2003GL018035, 2003.

Meskhidze, N., Chameides, W., and Nenes, A.: Dust and Pollution: A Recipe for Enhanced Ocean Fertilization?, J. Geophys. Res., 110, D03301, doi:10.1029/2004JD005082, 2005.

Mihalopoulos, N., Stephanou, E., Kanakidou, M., Pilitsidis, S., and Bousquet, P.: Troposheric aerosol ionic composition above the eastern Mediterranean area, Tellus B, 49, 314-326, 1997.

Moore, R. H. and Nenes, A.: Scanning Flow CCN Analysis-A method for fast measurements of CCN spectra, Aerosol Sci. Tech., 43, 1992-1207, 2009.

Myriokefalitakis, S., Tsigaridis, K., Mihalopoulos, N., Sciare, J., Nenes, A., Kawamura, K., Segers, A., and Kanakidou, M.: Incloud oxalate formation in the global troposphere: a 3-D modeling study, Atmos. Chem. Phys., 11, 5761-5782, doi:10.5194/acp11-5761-2011, 2011.

Myriokefalitakis, S., Daskalakis, N., Mihalopoulos, N., Baker, A. R., Nenes, A., and Kanakidou, M.: Changes in dissolved iron deposition to the oceans driven by human activity: a 3-D global modelling study, Biogeosciences, 12, 3973-3992, doi:10.5194/bg-12-3973-2015, 2015.

Nenes, A., Krom, M. D., Mihalopoulos, N., Van Cappellen, P., Shi, Z., Bougiatioti, A., Zarmpas, P., and Herut, B.: Atmospheric acidification of mineral aerosols: a source of bioavailable phosphorus for the oceans, Atmos. Chem. Phys., 11, 6265-6272, doi:10.5194/acp-11-6265-2011, 2011.

Ng, N. L., Herndon, S. C., Trimborn, A., Canagaratna, M. R., Croteau, P. L., Onasch, T. B., Sueper, D., Worsnop, D. R., Zhang, Q., Sun, Y. L., and Jayne, J. T.: An Aerosol Chemical Speciation Monitor (ACSM) for routine monitoring of the composition and mass concentration of ambient aerosol, Aerosol Sci. Tech., 45, 780-794, 2011.

Nguyen, T. K. V., Petters, M. D., Suda, S. R., Guo, H., Weber, R. J., and Carlton, A. G.: Trends in particle-phase liquid water during the Southern Oxidant and Aerosol Study, Atmos. Chem. Phys., 14, 10911-10930, doi:10.5194/acp-14-10911-2014, 2014.

Nowak, J. B., Huey, L. G., Russell, A. G., Tian, D., Neuman, J. A., Orsini, D., Sjostedt, S. J., Sullivan, A.P., Tanner, D. J., Weber, R. J., Nenes, A., Edgerton, E., and Fehsenfeld, F. C.: Analysis of urban gas phase ammonia measurements from the 2002 Atlanta Aerosol Nucleation and Real-Time Characterization Experiment (ANARChE), J. Geophys. Res., 111, D17308, doi:10.1029/2006jd007113, 2006.

Petters, M. D. and Kreidenweis, S. M.: A single parameter representation of hygroscopic growth and cloud condensation nucleus activity, Atmos. Chem. Phys., 7, 1961-1971, doi:10.5194/acp-71961-2007, 2007.

Pilinis, C., Pandis, S. N., and Seinfeld, J. H.: Sensitivity of Direct Climate Forcing by Atmospheric Aerosols to Aerosol-Size and Composition, J. Geophys. Res.-Atmos., 100, 18739-18754, doi:10.1029/95jd02119, 1995.

Pöschl, U. and Shiraiwa, M.: Multiphase chemistry at the atmosphere-biosphere interface influencing climate and public health in the Anthropocene, Chem. Rev., 115, 4440-4475, doi:10.1021/cr500487s, 2015.

Roberts, G. C. and Nenes, A.: A continuous-flow streamwise thermal-gradient $\mathrm{CCN}$ chamber for atmospheric measurements, Aerosol Sci. Tech., 39, 206-221, doi:10.1080/027868290913988, 2005.

Sciare, J., Oikonomou, K., Cachier, H., Mihalopoulos, N., Andreae, M. O., Maenhaut, W., and Sarda-Estève, R.: Aerosol mass closure and reconstruction of the light scattering coefficient over the Eastern Mediterranean Sea during the MINOS campaign, Atmos. Chem. Phys., 5, 2253-2265, doi:10.5194/acp-5-2253-2005, 2005.

Sheridan, P. J.: Spatial variability of submicrometer aerosol radiative properties over the Indian Ocean during INDOEX, J. Geophys. Res., 107, INX2 10-1-INX2 10-17, doi:10.1029/2000jd000166, 2002.

Shi, Z., Krom, M. D., Jickells, T. D., Bonneville, S., Carslaw, K. S., Mihalopoulos, N., Baker, A. R., and Benning, L. G.: Impacts on iron solubility in the mineral dust by processes in the source region and the atmosphere: A review, Aeol. Res., 5, $21-$ 42, doi:10.1016/j.aeolia.2012.03.001, 2012.

Solmon, F., Chuang, P. Y., Meskhidze, N., and Chen, Y.: Acidic processing of mineral dust iron by anthropogenic compounds over the north Pacific Ocean, J. Geophys. Res.-Atmos., 114, D02305, doi:10.1029/2008JD010417, 2009.

Spindler, G., Hesper, J., Brüggemann, E., Dubois, R., Müller, Th., and Herrmann, H.: Wet annular denuder measurements of nitrous acid: laboratory study of the artefact reaction of $\mathrm{NO}_{2}$ with $\mathrm{S}(\mathrm{IV})$ in aqueous solution and comparison with field measurements, Atmos. Environ., 37, 2643-2662, 2003.

Stavroulas, I., Bougiatioti, A., Kouvarakis, G., Theodosi, C., Zarmpas, P., Nikolaou, P., and Mihalopoulos, N.: Long-term chemical characterization of fine particulate matter over the Eastern Mediterranean at high temporal resolution, Atmos. Chem. Phys. Discuss., submitted, 2016.

Stein, A. F., Draxler, R. R., Rolph, G. D., Stunder, B. J. B., Cohen, M. D., and Ngan, F.: NOAA's HYSPLIT Atmospheric Transport and Dispersion Modeling System, B. Am. Meteorol. Soc., 96, 2059-2077, doi:10.1175/BAMS-D-14-00110.1, 2015.

Stumm, W. and Morgan, J. J.: Aquatic Chemistry, WileyInterscience, New York, 1996.

Surratt, J. D., Lewandowski, M., Offenberg, J. H., Jaoui, M., Kleindienst, T. E., Edney, E. O., and Seinfeld, J. H.: Effect of acidity on secondary organic aerosol formation from isoprene, Environ. Sci. Technol., 41, 5363-5369, doi:10.1021/es0704176, 2007.

Surratt, J. D., Chan, A. W., Eddingsaas, N. C., Chan, M., Loza, C. L., Kwan, A. J., Hersey, S. P., Flagan, R. C., Wennberg, P. O., and Seinfeld, J. H.: Reactive intermediates revealed in secondary organic aerosol formation from isoprene, P. Natl. Acad. Sci. USA, 107, 6640-6645, doi:10.1073/pnas.0911114107, 2010.

Weber, R. J., Guo, H., Russel, A. G., and Nenes, A.: High aerosol acidity despite declining atmospheric sulfate concentrations over the past 15 years, Nat. Geosci., 9, 282-285, doi:10.1038/ngeo2665, 2016.

Wyers, G. P., Otjes, R. P., and Slanina, J.: A continuous-flow denuder for the measurement of ambient concentrations and surface-exchange fluxes of ammonia, Atmos. Environ., 27, 2085-2090, 1993.

Zhang, Z., Gao, J., Engling, G., Tao, J., Chai, F., Zhang, L., Zhang, R., Sang, X., Chan, C., Lin, Z., and Cao, J.: Characteristics and applications of size-segregated biomass burning tracers in China's Pearl River Delta region, Atmos. Environ., 102, 290301, 2015. 